\author{
Ladislav KANDRÁČ \\ Ildikó MAŇKOVÁ ${ }^{2}$ \\ Marek VRABEL ${ }^{3}$
}

\title{
CUTTING EDGE PREPARATION IN MACHINING PROCESSES
}

\begin{abstract}
In modern manufacturing industry it is essential to produce under low costs and high quality of products in a short time. This is possible by selecting the cutting parameters in order to achieve high accuracy and low processing time. Usually the desired cutting parameters are determined based on experience or by use of various handbooks but the cutting tool capability is not fully employed. The tool wear has detrimental effect on surface roughness and costs of production as well as on cutting tool performance and machining process reliability. The meso- and microgeometries of tool design have long been poorly considered by end users and by researchers, because of the lack of manufacturing procedure leading to accurate edge radius preparation. The problem of cutting edge preparation requires considering the appropriate integration of the following aspects: workpiece, machining process, machine tool, surroundings and cutting tool. The application of the edge preparation process seeks to solve this problem by means of the elimination of defects and irregularities and by the generation of defined edge geometry and by modifying the micro-topography of the edge and the micro-structuring of the face and flank of the tool. This article is an outline of literature knowledge concerning the cutting edge design and cutting edge preparation.
\end{abstract}

Keywords: cutting edge preparation, cutting edge geometry, micro geometry

\section{Introduction}

In modern manufacturing industry it is essential to produce under low costs and high quality of products in a short time. This is possible by selecting the cutting parameters for achieving high accuracy and low processing time. Usually the desired cutting parameters are determined based on experience or by use of various handbooks but the cutting tool capability is not fully employed. The tool

\footnotetext{
${ }^{1}$ Autor do korespondencji/corresponding author: Ladislav Kandráč, Technical University in Košice, Mäsiarska 74, 04001 Košice, Slovakia, tel.: +421 556023502, e-mail: ladislav. kandrac@tuke.sk

2 Ildikó Maňková, Technical University in Košice, Mäsiarska 74, 04001 Košice, Slovakia, e-mail: ildiko.mankova@tuke.sk

${ }^{3}$ Marek Vrabel', Technical University in Košice, Mäsiarska 74, 04001 Košice, Slovakia, e-mail: marek.vrabel@tuke.sk
} 
wear has detrimental effect on surface roughness and costs of production as well as on cutting tool performance and machining process reliability. Essential factor is the cutting edge micro-geometry, which affects the tool wear, process reliability and quality of the workpiece. Research activities in the field of cutting tools are concentrated on analyzing the process of cutting edge preparation. Furthermore, the methods for assessing the quality of the rake and flank surfaces on cutting tool of the instrument and in particular the impact of cutting edge radius $r_{n}$ of machined surface properties and its micro-geometry have been presented. In addition, cutting edge preparation in drills and milling tools has significant impact on the burr formation on workpiece surface. The cutting edge changes due to accelerated wear of the running area significantly affect machined surface. In precision machining mainly in drilling and milling (ball end-mills, manufacturing of precision holes) problem arises in the evaluation and measurement of tool wear. Active faces of tool - flank and rake, are not simple flat surface such as and crater wear measurement is really a problem with classical measuring procedure. At present various methods of cutting edge preparation are used and developed for precision machining tools (laser, honing, blasting etc.) where the monitoring of quality expressed by cutting edge sharpness and its micro-geometrical parameters, requires suitable measuring methods. The precise measurements are applied in micro-and nano-metrology measurement procedures. Similarly, manufacturers of precision and complex shape cutting tools look for opportunities how in production conditions apply nanometrological measurement procedures.

During last decade a great interest has been done to cutting edge preparation. This interest arises from more aspects among them the necessity to prepare the tool edge before coatings as well as demand for high precision tool design with the aim of smooth and sharp cutting edge. Moreover, the requirements of quality of the finished product, decrease of costs, flexibility, reduced times of production, productivity, capacity to process new materials and miniaturization are among others. High material removal rate, high cutting parameters require high tool performance. Therefore, the geometry of the cutting edge and its preparation play a significant role on the performance of a cutting tool when machining widely used or difficult-to-machine materials. The selection of the most recent publication concerned with cutting tool edge preparation is listed in Table 1.

\section{Cutting edge preparation}

It is well known that cutting tools are subjected to high stresses by modern machining technologies, like dry machining, high-speed machining or highperformance machining. Several researchers state [1-13] that the central goal of the cutting edge preparation process is to generate a specific geometry in the contour of the cutting edge (rounding or chamfer or combination of both), and to 
produce an improvement in the cutting edge micro topography (notchedness or chipping) and to adapt the surface of the cutting edge and cutting surfaces for the subsequent coating process of the cutting tool or for the improvement of the contact behavior for an specified machining application. The cutting edge micro geometry is often defined by the cutting edge radius $r_{n}$. The shape of the microgeometry can be consistently characterized using the parameters $\Delta r, \varphi, S \gamma, S \alpha$ proposed by Denkena as it is illustrated in Fig. 1 .

Table 1. Analysis results of the published works from cutting edge preparation

\begin{tabular}{|c|c|c|c|c|}
\hline $\begin{array}{l}\text { Author } \\
\text { Year }\end{array}$ & $\begin{array}{l}\text { Cutting } \\
\text { material }\end{array}$ & Processes & $\begin{array}{c}\text { Edge } \\
\text { design }\end{array}$ & Purpose of study \\
\hline $\begin{array}{c}\text { Wyen- } \\
\text { Wegener } \\
2010[6]\end{array}$ & $\mathrm{HW}$ insert & $\begin{array}{l}\text { micro-abra- } \\
\text { sive jet machi- } \\
\text { ning }\end{array}$ & $\begin{array}{l}\text { rounded edge, } \\
\text { edge radius }\end{array}$ & $\begin{array}{l}\text { determination a new algo- } \\
\text { rithm to reduce uncer- } \\
\text { tainties of existing methods }\end{array}$ \\
\hline $\begin{array}{c}\text { Denkena } \\
\text { et al. } 2012 \text { [7] }\end{array}$ & $\begin{array}{l}\mathrm{HC} \text { with } \\
\text { TiAlN-Al }{ }_{2} \mathrm{O}_{3} \\
\text { coating }\end{array}$ & $\begin{array}{l}\text { abrasive } \\
\text { brushing }\end{array}$ & $\begin{array}{l}\text { cutting edge } \\
\text { design, cham- } \\
\text { fer }\end{array}$ & $\begin{array}{l}\text { investigate the effect of } \\
\text { tailored cutting edge micro- } \\
\text { geometry }\end{array}$ \\
\hline $\begin{array}{c}\text { Denkena } \\
\text { et al. } 2013[8]\end{array}$ & $\begin{array}{l}\text { HW K10-20 } \\
\text { insert }\end{array}$ & $\begin{array}{l}\text { face } \\
\text { grinding }\end{array}$ & $\begin{array}{l}\text { cutting edge } \\
\text { design, cham- } \\
\text { fer }\end{array}$ & $\begin{array}{l}\text { novel method for preparing } \\
\text { of customized cutting edges } \\
\text { by means of grinding }\end{array}$ \\
\hline $\begin{array}{c}\text { Yussefian } \\
\text { et al. } 2010 \text { [9] }\end{array}$ & $\begin{array}{l}\text { HSS T-15, } \\
\text { HW C-2 } \\
\text { uncoated } \\
\text { inserts }\end{array}$ & $\begin{array}{l}\text { electro-ero- } \\
\text { sion honed } \\
(\mathrm{EDM})\end{array}$ & $\begin{array}{l}\text { rounded edge, } \\
\text { honed edge, } \\
\text { edge radius }\end{array}$ & $\begin{array}{l}\text { electro-erosion edge honing } \\
\text { of cutting tools }\end{array}$ \\
\hline $\begin{array}{l}\text { Bassett et al. } \\
2012[11]\end{array}$ & $\begin{array}{l}\text { HC with TiN- } \\
\text { TiAlN coating }\end{array}$ & $\begin{array}{l}\text { abrasive } \\
\text { brushing }\end{array}$ & $\begin{array}{l}\text { honed edge } \\
\text { design, cham- } \\
\text { fer }\end{array}$ & $\begin{array}{l}\text { study presents the quality } \\
\text { oriented cutting edge prepa- } \\
\text { ration via abrasive brushing }\end{array}$ \\
\hline
\end{tabular}

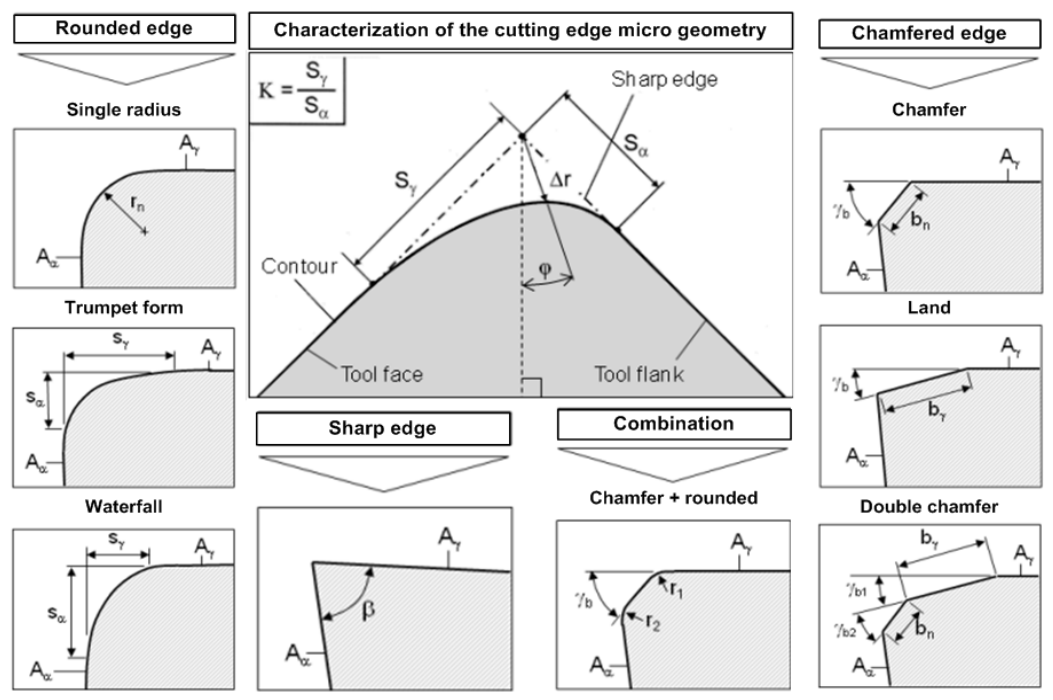

Fig. 1. Characterization of the cutting edge micro geometry and typical cutting edge preparation geometries 
Denkena et al. [3] analyzed the influence of asymmetrical micro geometries on tool life. It is demonstrated that the slope of the edge towards the flank or rake face influences not only the wear mechanism, but also the mechanical and thermal loads. To achieve special micro geometries at the cutting edges, different manufacturing technologies can be applied depending on the productivity, precision and final micro geometry. Denkena [13] classified three kinds of characterization of the micro-geometry which are possible to distinguish three tendencies (Table 2).

Table 2. Characterization of the insert micro geometry by " $K$ " factor

\begin{tabular}{|c|l|}
\hline Factor " $K$ " & \multicolumn{1}{|c|}{ Characterization of type tendencies } \\
\hline$K=1$ & defines a symmetrical micro geometry \\
\hline$K>1$ & indicates a slope toward the rake face \\
\hline$K<1$ & describes a slope towards flank face \\
\hline
\end{tabular}

As mentioned [2] tool designers pay particular attention on the tool geometry at various scale: macro-geometry (cutting angles, chipbreaker etc.), mesogeometry (cutting edge radius - order of magnitude: $1 \div 100 \mu \mathrm{m}$ ), and finally micro-geometry (surface texture - order of magnitude $<1 \mu \mathrm{m}$ ). The meso- and micro-geometries of tool design have long been poorly considered by end users and by researchers, because of the lack of manufacturing procedure leading to accurate edge radius. These types of edge preparation are typical for different application and cutting tool materials, as shows Table 3. The problem of cutting edge preparation requires considering the appropriate integration of the following aspects: workpiece (material, shape and dimensions), machining process (kinematics, cutting conditions), machine tool (static and dynamic rigidity), surroundings (cutting fluid, thermal conditions) and cutting tool (substrate, coating, macro geometry and cutting edge preparation) as shown in Fig. 2.

Table 3. Common applications and employed material for specific type of cutting edge

\begin{tabular}{|l|l|l|}
\hline $\begin{array}{c}\text { Type } \\
\text { of cutting edge }\end{array}$ & \multicolumn{1}{c|}{ Common applications } & \multicolumn{1}{c|}{ Commonly used } \\
\hline Rounded edge & $\begin{array}{l}\text { - finish cutting } \\
\text { - semi-finish cutting } \\
\text { - precision machining } \\
\text { - micromachining }\end{array}$ & $\begin{array}{l}\text { - diamond } \\
\text { - PCD (polycrystalline diamond) } \\
\text { - HSS (high speed steel) } \\
\text { - cemented carbide tools }\end{array}$ \\
\hline Chamfered edge & $\begin{array}{l}\text { - hard turning } \\
\text { - heavy rough cutting } \\
\text { - interrupted cutting }\end{array}$ & $\begin{array}{l}\text { - CBN (cubic boron nitride) } \\
\text { - PCBN (polycrystalline cubic boron nitride) } \\
\text { - ceramic tools }\end{array}$ \\
\hline
\end{tabular}



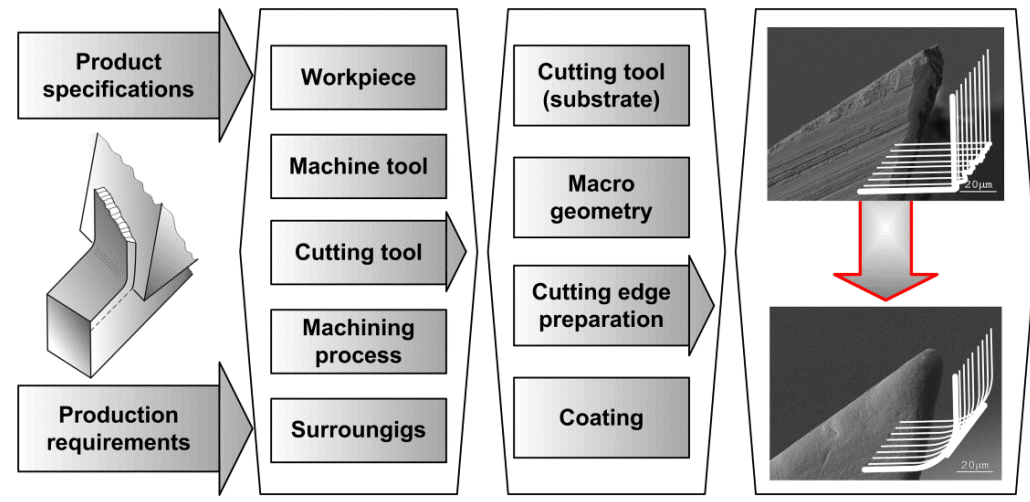

Fig. 2. General aspects of the problem framework, according to [1, 14]

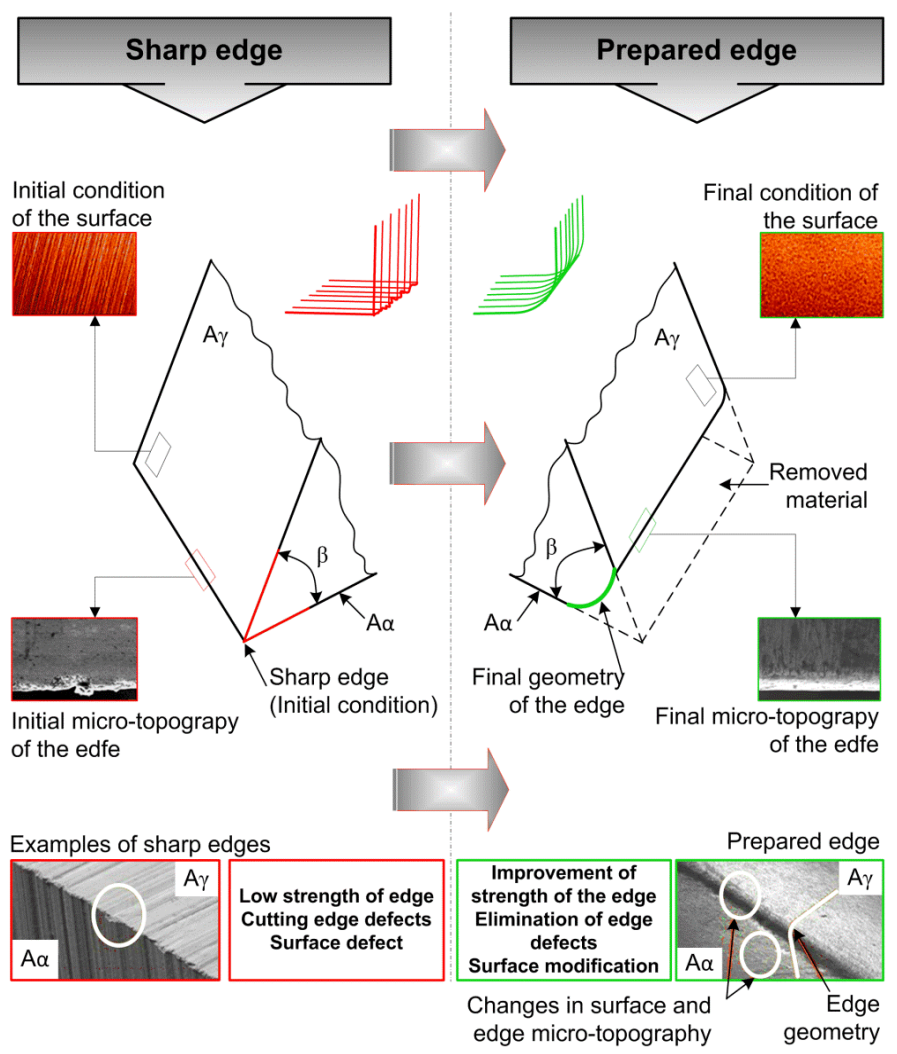

Fig. 3. Input-output aspects of the cutting edge preparation process, according to [1]

Rodriguez [1] shows two states of a cutting edge (Fig. 3), in the left side a sharp edge and in the right side a prepared edge. Before the cutting edge prepa- 
ration process, the sharp cutting edge presents typical edge defects (burrs, burns, micro fractures, poor surface roughness and irregularities), surface defects and low mechanical strength that cause chipping of the edge and instability of the cutting process obtaining low tool life, low tool reliability and negative influence on the workpiece quality. The application of the edge preparation process seeks to solve this problem by means of the elimination of defects and irregularities and by the generation of defined edge geometry and by modifying the microtopography of the edge (notchedness) and the microstructuring of the face and flank of the tool (right side of Fig. 3). The consideration of these cutting preparation aspects influences the cutting process causing improvements in tool life, tool reliability and workpiece quality. Cutting edge preparation consists of generating the cutting edge geometry and modifying the micro topography of the edge (change in notchedness) as well as the change in roughness and texture of the tool surfaces (face and flank) in the vicinity of the edge, with the consequent elimination of edge defects and strength improvement, in order to improve the performance and reliability of the cutting tool and the quality of the workpiece.
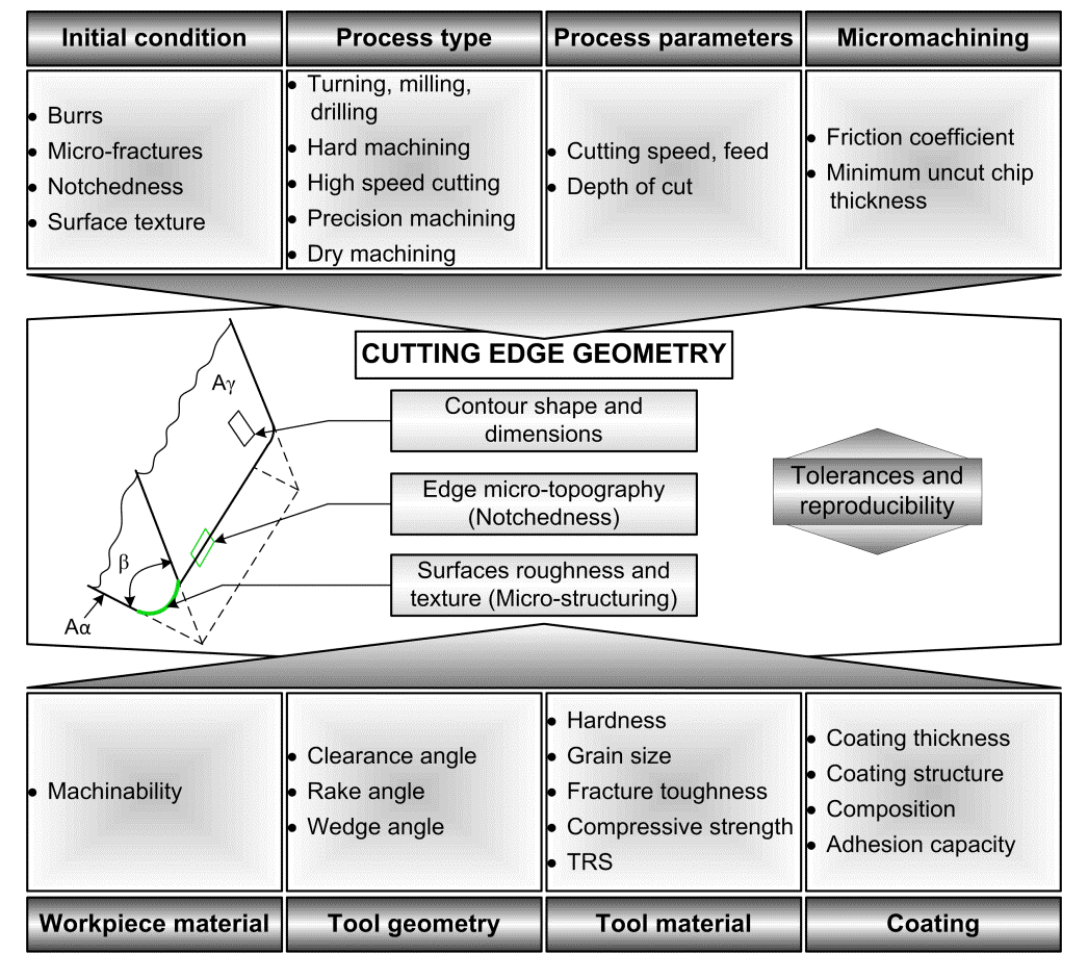

Fig. 4. Factors influencing the selection and design of the cutting edge geometry, according to $[1,15]$ 
In order to define the adequate cutting edge geometry and preparation for a specific application, it is required to consider the following aspects (Fig. 4):

- initial condition of the cutting edge,

- type of machining process,

- process parameters,

- size effect and/or micro-machining aspects,

- workpiece material,

- tool material (substrate),

- cutting tool macro geometry,

- required coating.

The cutting edge preparation process generates the contour of the cutting edge, changes the micro topography of the cutting edge, and also modifies the micro-structuring of the surfaces in the vicinity of the edge.

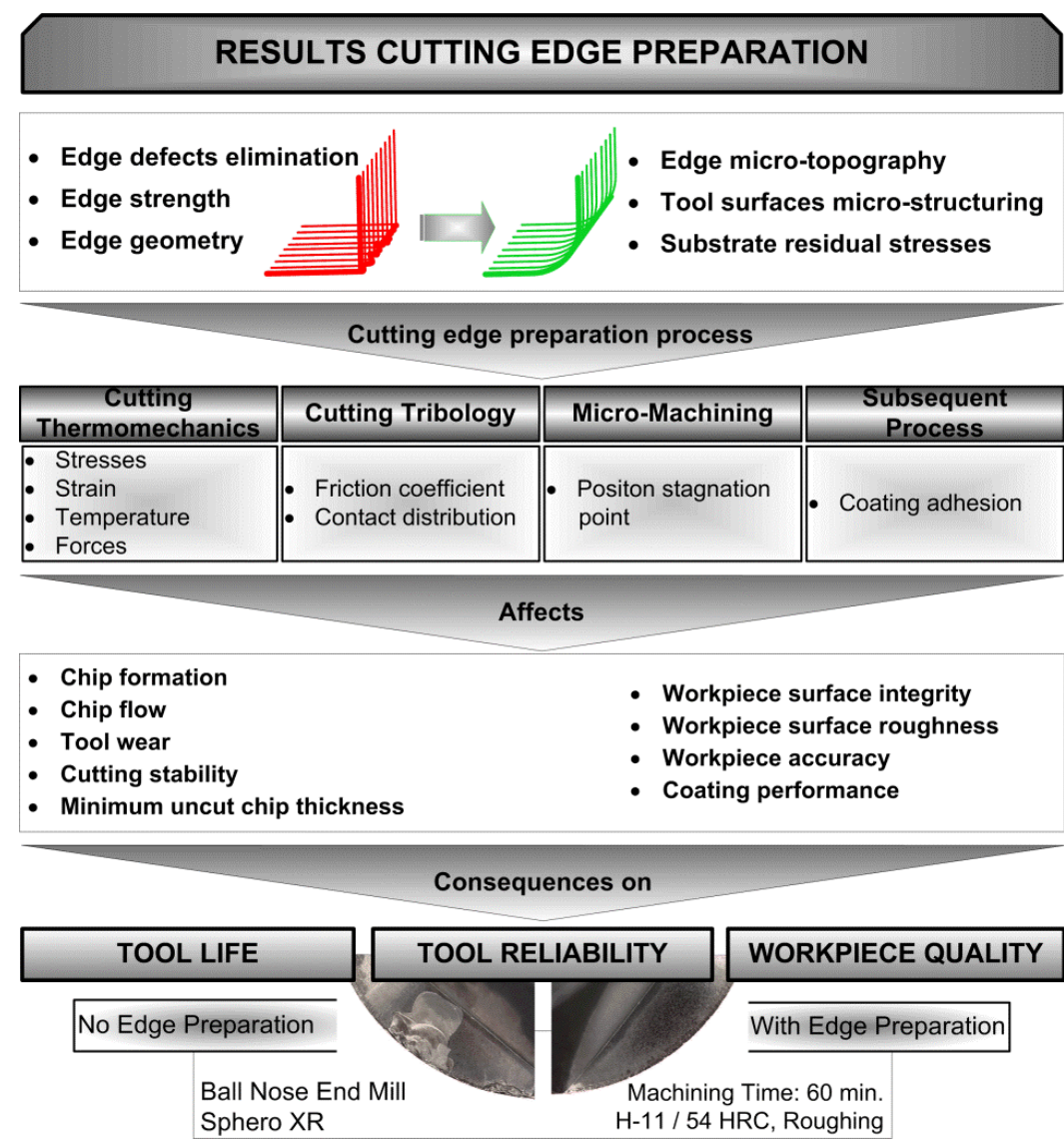

Fig. 5. Influence of the cutting edge preparation on the machining process: chain of effects, according to [1, 14-16] 
These aspects of the cutting edge preparation influence the cutting process. As a result consequences on the tool performance and workpiece quality are observed. Figure 5 shows an example chain of influences, effects and consequences of the edge preparation on the machining process for typical ball end mill. In Figure 6 the categories used for the definition of the geometry of the cutting edge and an example of a scanned cutting edge obtained with a chromatic sensor used to characterize the edge rounding are shown. Rodriguez [1] states that these categories allow the characterization of the cutting edge preparation by means of quantifiable parameters using the appropriate measurement technology. The characteristic of the contours that describe the convex surface generated by the rounding process is considered as important aspect. The characteristic of these contours can be carried out by means of a nominal radius of rounding $r_{n}$ that corresponds to the best fit of the contour to a circumference arch or more detailed through the curvature function that represents the curvature and the radius in each point of the contour.
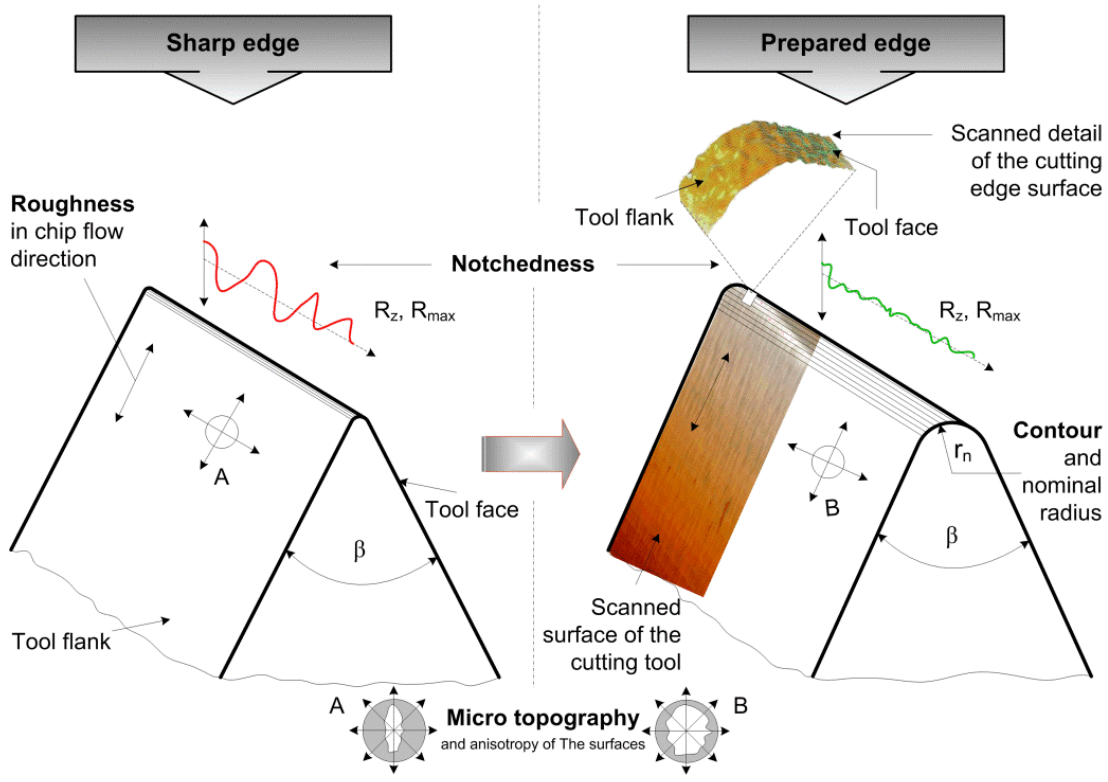

Fig. 6. Characterization and scanned detail of cutting edge, according to $[1,14]$

\section{Conclusions}

The cutting edge preparation shows positive effect on the performance of the precision cutting tool. The geometry of the cutting edge, in terms of nominal radius, as well as the notchedness and the micro-structuring of the tool face and tool flank has relevant influence on the performance of the precision cutting tool. 
This aspect can be used to improve ostensibly the quality of the precision cutting tool. Thus, a relative low investment in the preparation process, compared with other processes in the production chain of precision cutting tools, can result in a high increase in reliability and tool life.

An important aspect is the definition of the measurement methodology, based principally on optic technology by using contactless measurement a 3D modeling of active part of cutting tool. Planning the cutting edge preparation process is a strategic aspect to obtain the required characteristics of the mesoand microgeometry of the cutting tools. The cutting edge preparation plays an important role, especially in the first stage of machining, at the beginning of the tool-life. The characteristic of the first contact between cutting edge and workpiece defines the later performance of the cutting tool. Literature review shows that the cutting edge without preparation fails in the first stage of the machining, generating an accelerated wear of the tool flank. The cutting forces and the force ratio are lower for the unprepared sharp cutting edges (with small radius) in the first stage of the machining, later appear critical points where the forces and force ratio for the prepared edges begin to be lower than for the unprepared edge.

\section{References}

[1] Rodriguez C.J.C.: Cutting edge preparation of precision cutting tools by applying micro-abrasive jet machining and brushing, Kassel University Press GMBH, Kassel 2009.

[2] Rech J., Yen Y.-C., Schaff M.J., Hamdi H., Altan T., Bouzakis K.D.: Influence of cutting edge radius on the wear resistance of PM-HSS milling inserts, Wear, 259 (2005), 1168-1176.

[3] Denkena B., Lucas A., Basset E.: Effects of the cutting edge micro geometry on tool wear and its thermo-mechanical load, CIRP J. Manuf. Sci. Technology, 4 (2011), 73-76.

[4] Denkena B., García L., Basset E., Rehe M.: Cutting edge preparation by means of abrasive brushing, Key Eng. Materials, 438 (2010), 1-7.

[5] Biermann D., Terwey I.: Cutting edge preparation to improve drilling tools for HPC processes, CIRP J. Manuf. Sci. Technology, 1 (2008), 76-80.

[6] Wyen C.-F., Wegener K.: Influence of cutting edge radius on cutting forces in machining titanium, CIRP Annals - Manuf. Technology, 59 (2010), 93-96.

[7] Denkena B., Koehler J., Rehe M.: Influence of the honed cutting edge on tool wear and surface integrity in slot milling of $42 \mathrm{CrMo} 4$ steel, Procedia CIRP, 1 (2012), 190-195.

[8] Denkena B., Köhler J., Ventura C.E.H.: Customized cutting edge preparation by means of grinding, Precision Engineering, 34 (2013), 1-9.

[9] Yussefian N.Z., Koshy P., Buchholz S., Klocke F.: Electro-erosion edge honing of cutting tools, CIRP Annals - Manuf. Technology, 59 (2010), 215-218. 
[10] Aurich J.C., Zimmermann M., Leitz L.: The preparation of cutting edges using a marking laser, Prod. Eng. Res. Devel, 5 (2011), 17-24.

[11] Bassett E., Köhler J., Denkena B.: On the honed cutting edge and its side effects during orthogonal turning operations of AISI1045 with coated WC-Co inserts, CIRP J. Manuf. Sci. Technology, 5 (2012), 108-126.

[12] Fang N., Wu Q.: The effects of chamfered and honed tool edge geometry in machining of three aluminum alloys, Int. J. Mach. Tools Manuf., 45 (2005), 1178 1187.

[13] Denkena B., León-Garcia L., Bassett E.: Preparation of designed cutting edge microgeometries by simultaneous 5 -axes brushing. Proc. of $3^{\text {rd }}$ Int. Conf. Manufacturing Engineering, Berlin 2008, 117-124.

[14] Cselle et al.: Influence of edge preparation on the performance of coated cutting tools, Int. Conf. Metallurgical Coatings and Thin Films, San Diego 2007.

[15] Tapp M.: Cutting tool coatings and edge preparation, FRAISA 2011, pp. 1-37.

[16] Cheung F.Y., Zhou Z.F., Geddam A., Li K.Y.: Cutting edge preparation using magnetic polishing and its influence on the performance of high-speed steel drills, J. Mat. Proc. Technol., 208 (2008), 196-204.

\section{Acknowledgement}

This work was supported by the Slovak Research and Development Agency under the contract No DO7RP-0014-09 and granted research project VEGA 1/0279/11'Integration of trials, numerical simulation and neural network to predict cutting tool performance" as well as the APVV SK-AT-0021-12 bilateral project "Implementation of nanometrological process management model into cutting tool edge assessment in precision machining”.

\section{PRZYGOTOWANIE KRAWĘDZI OSTRZA W PROCESIE OBRÓBKI SKRAWANIEM}

\section{Streszczenie}

W nowoczesnym przemyśle wytwórczym ważne jest, aby produkować niskimi kosztami i uzyskiwać wysoką jakość produktów w krótkim czasie. Jest to możliwe poprzez wybranie parametrów cięcia w celu uzyskania dużej dokładności i krótkiego czasu wytwarzania. Zazwyczaj pożądane parametry skrawania są ustalane na podstawie doświadczeń lub wiedzy podręcznikowej, ale w takich warunkach możliwości narzędzi do obróbki skrawaniem nie są w pełni wykorzystane. Zużycie narzędzia ma niekorzystny wpływ zarówno na chropowatość powierzchni wyrobu i koszty produkcji, jak również na wydajność cięcia narzędzia oraz niezawodność procesu obróbki. Meso- oraz mikrogeometria projektowanych narzędzi długo nie była brana pod uwage przez użytkowników ze względu na brak procedur produkcyjnych pozwalających na dokładne wykonanie promienia krawędzi ostrza. Przygotowanie krawędzi ostrza wymaga uwzględnienia odpowiedniej integracji takich aspektów, jak: przedmiot obrabiany, proces obróbki, obrabiarka, środowisko obróbki i narzędzie. Zastosowanie procesu przygotowania krawędzi ma na celu rozwiązanie tego problemu przez wyeliminowanie wad i nieprawidłowości, przez wygenerowanie 
określonej geometrii krawędzi, przez modyfikację mikrotopografii krawędzi i mikrobudowę powierzchni czołowej oraz powierzchni bocznej narzędzia. Praca przedstawia zarys wiedzy na temat projektowania i przygotowywania krawędzi narzędzia.

Słowa kluczowe: przygotowanie krawędzi ostrza, geometria krawędzi ostrza, mikrogeometria

DOI:10.7862/rm.2013.14

Otrzymano/received: 2.06 .2013

Zaakceptowano/accepted: 25.06.2013 